\title{
PERANAN AUDIT INTERN PIUTANG UNTUK MENINGKATKAN KELANCARAN PENYELESAIAN PROYEK DAN EFEKTIVITAS PENDAPATAN PADA PT. BUKAKA TEKNIK UTAMA, TBK
}

\author{
Retno Martanti Endah L \\ Dosen Tetap Fakultas Ekonomi \\ Universitas Pakuan \\ Cytra Anggy Mulyono \\ Mahasiswa Fakultas Ekonomi \\ Universitas Pakuan
}

\begin{abstract}
ABSTRAK
Perusahaan didirikan dengan tujuan tertentu antara lain untuk menunjang kegiatan perusahaan, memenuhi kebutuhan masyarakat terhadap barang dan jasa, yang paling penting bertujuan untuk mendapatkan laba yang layak. Penyelesaian proyek didefinisikan sebagai suatu rangkaian kegiatan yang hanya terjadi sekali, dimana pelaksanaannya sejak awal sampai akhir dibatasi oleh kurun waktu tertentu. Hasil pembayaran tagihan/piutang atas kemajuan proyek tersebut merupakan sumber dana untuk menyelesaikan proyek tersebut sampai selesai. Dengan demikian pengelolaan tagihan atau piutang proyek merupakan salah satu aspek yang penting bagi kelangsungan hidup efektivitas pendapatan dan profitabilitas perusahaan.
\end{abstract}

Tujuan penelitian dilakukan adalah untuk mengetahui peranan audit intern piutang untuk meningkatkan kelancaran penyelesaian proyek dan efektivitas pendapatan pada PT Bukaka Teknik Utama, Tbk. Jenis penelitian ini deskriptif eksploratif serta dengan menggunakan analisis kualitatif. Dalam penelitian ini terdapat dua variabel terkait, yakni variabel bebas / independen peranan audit intern piutang dan variabel dependen yaitu meningkatkan kelancaran penyelesaian proyek dan efektivitas pendapatan.

Perputaran piutang pada PT Bukaka Teknik Utama menunjukkan adanya fluktuatif penurunan dan peningkatan, penurunan perputaran piutang tersebut menunjukkan jangka waktu penerimaan atau perolehan atas piutang semakin lama, sehingga menimbulkan risiko timbulnya piutang tak tertagih, sehingga peranan internal audit sangat diperlukan untuk meningkatkan kelancaran penyelesaian proyek dan efektivitas pendapatan.

Kata Kunci : Kelancaran penyelesaian proyek, Efektivitas pendapatan , Peranan audit intern piutang

\section{Pendahuluan}


Perusahaan didirikan dengan tujuan tertentu antara lain untuk menunjang kegiatan perusahaan, memenuhi kebutuhan masyarakat terhadap barang dan jasa, meningkatkan kesejahteraan pegawai serta yang paling penting bertujuan untuk mendapatkan laba yang layak. Agar dapat menjaga kelangsungan hidupnya, maka kegiatannya harus dibuat pola perencanaan, baik dibidang penjualan dengan memperhatikan seluruh komponen yang ada dalam perusahaan, terutama yang menunjang terciptanya laba yang banyak.

Masalah penjualan sebagai salah satu sumber pendapatan perusahaan perlu mendapat perhatian besar. Perusahaan harus mendapatkan kepastian tentang penerimaan hasil penjualannya, kebocoran-kebocoran yang terjadi dalam penerimaan penjualan sedapat mungkin harus dihindari, karena hal ini secara langsung dapat mempengaruhi kelangsungan hidup perusahaan. Laba tidak hanya dapat dicapai dengan peningkatan jumlah persediaan barang atau jasa, tetapi peningkatan ini harus diikuti pula dengan peningkatan penjualan.

Pos penting yang sangat mempengaruhi kelangsungan hidup perusahaan selain pendapatan adalah piutang. Bagi kebanyakan perusahaan, piutang merupakan pos yang penting karena merupakan bagian aset lancar perusahaan yang besar.

Internal audit dalam suatu perusahaan mempunyai peran sebagai fungsi kontrol dan membantu manajemen dalam melakukan pemeriksaan intern operasional perusahaan serta memberi masukan kepada manajemen melalui penerapan sistem pengendalian yang memadai, maupun dengan cara melakukan audit terhadap kegiatan operasi dalam rangka membantu seluruh tingkatan manajemen perusahaan agar dapat melaksanakan kewajibannya secara ekonomis, efisien, dan efektif.

PT Bukaka Teknik Utama, Tbk (PT Bukaka) merupakan perusahaan jasa yang bergerak dibidang engineering, konstruksi dan enerji terkemuka di Indonesia. Sebagaimana layaknya perusahaan yang listed di bursa efek memiliki sistem administrasi yang lebih transparann dan accountable atau yang dikenal dengan "sistem pengendalian intern" yang secara intern sangat berguna untuk memastikan efektivitas dan efisiensi penyelesaian proyek dan penagihan piutang PT Bukaka. Maka diperlukan internal audit yang memadai didalam suatu perusahaan, terutama perusahaan yang ruang lingkupnya cukup besar agar pengendalian intern perusahaan bisa berjalan secara baik dalam rangka menjaga aset dan modal perusahaan serta efisiensi dan efektivitas usahanya dan 
kelancaraan penyelesaian proyek perusahaan dapat tercapai sesuai dengan terget yang ditentukan.

Oleh karena itu tujuan penelitian ini dilakukan adalah 1) untuk mengetahui pelaksanaan audit intern piutang pada PT Bukaka Teknik Utama, Tbk. 2) untuk mengetahui upaya untuk meningkatkan kelancaran penyelesaian proyek dan efektivitas pendapatan PT Bukaka Teknik Utama, Tbk. 3) untuk mengetahui peranan audit intern piutang untuk meningkatkan kelancaran penyelesaian proyek dan efektivitas pendapatan pada PT Bukaka Teknik Utama, Tbk.

\section{Metode Penelitian}

Metode penelitian yang digunakan dalam penelitian ini adalah Studi Kasus, yaitu penelitian tentang subjek penelitian yang berkenaan dengan suatu tingkat dari keseluruhan personalitas. Teknik penelitian yang digunakan dalam penelitian ini adalah analisis kualitatif dan kuantitatif ( non-statistik ). Analisis kualitatif dan kuantitatif (nonstatistik) digunakan untuk menjelaskan perilaku faktor penyebab.

\section{Hasil dan Pembahasan}

3.1. Pelaksanaan Internal Audit atas Piutang Usaha pada PT Bukaka Teknik Utama, Tbk

Kegiatan pemeriksaan pada PT Bukaka Teknik Utama, Tbk dilakukan sesuai norma audit internal yang tercantum di dalam piagam audit internal memuat aspek penilaian atas perencanaan, pemeriksaan dan evaluasi informasi, pelaporan hasil audit dan tindak lanjut audit atad temuan-temuan yang diperoleh dari pemeriksaan tersebut. Untuk itu, perusahaan menerapkan pengelolaan piutang tak tertagih.

Dengan melaksanakan audit internal maka perusahaan dapat melakukan tindakan korektif jika menemukan kesalahan-kesalahan dan penyimpangan-penyimpangan terhadap piutang tak tertagih. Agar pelaksanaan audit internal dapat berjalan dengan baik, ada 4 (empat) faktor yang harus diperhatikan yaitu perencanaan, pemeriksaan dan evaluasi informasi, pelaporan hasil audit dan tindak lanjut audit.

3.2. Kelancaran Proyek dan Efektivitas Pendapatan pada PT Bukaka Teknik Utama, Tbk

Kegiatan pengelolaan piutang untuk meningkatkan kelancaran proyek dan efektivitas pendapatan pada PT Bukaka Teknik Utama dapat terlaksana ditentukan dari 
kebijakan yang diambil oleh perusahaan. Penjualan yang dilakukan oleh PT Bukaka Teknik Utama rentan terhadap terjadinya kerugian dan membuat tidak lancarnya penyelesaian proyek dan terhambatnya pendapatan yang disebabkan oleh tidak diterimanya piutang.

Agar usaha meningkatkan kelancaran penyelesaian proyek dan efektivitas pendapatan berjalan dengan baik, perlu memperhatikan Standar Operasional Prosedur (SOP) pendapatan, efektivitas pendapatan dan penerimaan pengumpulan piutang.

3.3. Peranan Audit Intern Piutang untuk Meningkatkan Kelancaran Penyelesaian Proyek dan Efektivitas Pendapatan pada PT Bukaka Teknik Utama, Tbk.

Dapat dilihat garis besar dari beberapa temuan audit serta berbagai permasalahan yang ada di PT Bukaka Teknik Utama, Tbk. dan berbagai rekomendasi yang diberikan agar dapat meningkatkan kelancaran penyelesaian proyek dan efektivitas pendapatan.

Meningkatkan kelancaran penyelesaian proyek dan efektivitas pendapatan terlihat dari perbandingan antara target pendapatan dan realisasi pendapatan, kebijakan pengumpulan piutang, tingkat perputaran piutang dilihat dari harinya, dan persentase piutang tak tertagih. Hal tersebut akan dijelaskan sebagai berikut :

a) PT Bukaka Teknik Utama, Tbk hanya melakukan apa yang dapat perusahaan capai bukan mencapai target yang sudah perusahaan tentukan. Maka dari itu perbandingan target dan realisasi pendapatan terlihat sangat tinggi perbedaannya. Hal ini mengakibatkan pendapatan perusahaan tidak tercapai sesuai dengan rencana perusahaan sesuai dengan target, dan pendapatan perusahaan tidak menjadi efektif.

b) Dari kebijakan pengumpulan piutang yang dilakukan, PT Bukaka Teknik Utama, Tbk hanya melakukan 3 kriteria. Pihak PT Bukaka Teknik Utama, Tbk tidak melakukan penyitaan peralatan perusahaan yang sudah melewati jauh dari tanggal jatuh tempo. Hal ini mengakibatkan kerugian kepada pihak perusahaan sendiri dengan membiarkan piutang yang semakin meningkat tiap tahunnya sehingga menimbulkan piutang tak tertagih.

c) Dari tingkat perputaran piutang terlihat dari setiap tahunnya mengalami konversi di tahun 2011 ke 2012 mengalami kenaikan, sedangkan di tahun 2012 ke 2013 mengalami penurunan. Bila dilihat dari jangka waktu penyelesaian proyek, perputaran piutang perusahaan berjalan dengan baik karena perputaran piutang dibawah jangka waktu penyelesaian proyek. 
Berdasarkan hasil konfirmasi kepada pihak manajemen Bukaka disampaikan bahwa beberapa debitur sedang mengalami kesulitan keuangan signifikan, kemungkinan dinyatakan pailit atau melakukan reorganisasi keuangan dan gagal bayar. Peningkatan tingkat tunggakan pembayaran merupakan indikator yang dianggap dapat menunjukkan adanya penurunan nilai piutang.

Peranan audit internal di PT Bukaka Teknik Utama, Tbk setiap tahunnya tidak mengalami peningkatan karena kurangnya pada pelaksanaan ataupun tindak lanjut sesuai tugas dan fungsi dari Internal Audit. Seiring penilaian pelaksanaan Internal Audit yang setiap tahunnya tidak meningkat dan pelaksanaan audit tindak lanjut audit yang tidak sesuai seperti yang sudah direncanakan ini mengakibatkan terhambatnya penyelesaian proyek dan piutang tak tertagih semakin fluktuatif meskipun jangka waktu penyelesaian proyek di bawah perputaran piutang per hari, untuk jangka waktu penyelesaian proyek masih baik dan penagihan tidak lewat dari batas waktunya.

Semakin menurunnya pelaksanaan Internal Audit dari tahun ke tahun ditambah persentase piutang yang bertambah ini menyebabkan piutang tak tertagih meningkat setiap tahunnya dengan kata lain pelaksanaan Internal Audit kurang atau belum berperan dengan sebagaimana mestinya dalam meningkatkan kelancaran penyelesaian proyek dan efektivitas pendapatan perusahaan dilihat dari pengelolaan dan pengumpulan piutangnya.

\section{Simpulan}

1) Internal Audit pada PT Bukaka Teknik Utama telah memprogramkan dan melaksanakan audit dari tahun 2011 sampai tahun 2012 yang meliputi perencanaan, pelaksanaan pemeriksaan dan evaluasi informasi, serta penilaian atas kecukupan sistem pengendalian dan kinerja terkait kebijakan system, realisasi pendapatan, prosedur pengumpulan dan pengelolaan piutang.

2) PT Bukaka Teknik Utama terdapat perbandingan antara terget pendapatan dan realisasi pendapatan, yang dilihat dari persentase tahun 2011 sampai 2013 terjadi fluktuasi.

3) Dilihat dari seluruh kondisi PT Bukaka Teknik Utama dalam kegiatan operasinya, peranan internal audit sangat diperlukan dalam upaya meningkatkan kelancaran 
penyelesaian proyek dan efektivitas pendapatan. Melalui perencanaan, pelaksanaan pemeriksaan dan evaluasi informasi, serta penilaian atas kecukupan sistem pengendalian dan kinerja, internal audit dapat memberikan masukan atau rekomendasi kepada manajemen.

\section{Daftar Pustaka}

Abdul Halim. 2008. Auditing 1 (Dasar-Dasar Audit Laporan Keuangan). UPP STIM YKPN, Yogyakarta

Akmal. 2006. Pemeriksaan Intern (Internal Audit). PT Indeks Kelompok Gramedia, Jakarta.

Amin Widjaja Tunggal. 2010. Dasar-dasar Audit Internal. Edisi Revisi. Harvarindo, Jakarta

Amin Widjaja Tunggal. 2012. The Internal Auditing Handbook. Harvarindo, Jakarta.

Amin Widjaja Tunggal. 2013. Akuntansi Intermediate (Pendekatan Tanya Jawab). Harvarindo, Jakarta.

Boynton, William C., Raymond N. Johnson, dan Walter G. Kell. 2003. Modern Auditing.

Edisi Ketujuh. Alih Bahasa: Ichsan Setiyo Budi dan Herman Wibowo. Jilid 1, Erlangga, Jakarta.

Darsono, P. 2009. Manajemen Keuangan. Nusantara Consulting. Jakarta

Hery. 2011. Akuntansi. Penerbit Gava Media.

Hiro Tugiman. 2006. Standar Profesional Audit Internal. Edisi Kesembilan. Kanisius. Jakarta.

Imam Santoso. 2007. Akuntansi Keuangan Menengah (Intermediate Accounting). Cetakan Pertama, PT Refika Aditama, Bandung

Mardi. 2011. Sistem Informasi Akuntansi. Cetakan Satu. Ghalia Indonesia, Bogor

Randal J Elder., Mark S Beasley., Alvin A Arens, dan Amir Abadi Jusuf. 2012. Jasa

Audit dan Assurance : Pendekatan Terpadu (Adaptasi Indonesia). Buku Satu.

Alih Bahasa: Desti Fitriani. Penerbit Salemba Empat, Jakarta.

Sanyoto Gondodiyoto. 2007. Audit Sistem Informasi (Pendekatan CobIT). Edisi Revisi.

Mitra Wacana Media. Jakarta.

Sukrisno Agoes. 2008. Auditing (Pemeriksaan Akuntan) oleh Kantor Akuntan Publik. Edisi Ketiga. Jilid 1 dan 2, Fakultas Ekonomi Universitas Indonesia, Jakarta. 
Peranan Audit Intern Piutang untuk Meningkatkan Kelancaran Penyelesaian Proyek dan Efektivitas Pendapatan pada PT Bukaka Teknik Utama, Tbk

Sutrisno. 2005. Manajemen Keuangan (Teori, Konsep dan Aplikasi), Edisi Pertama. Ekonosia, Yogyakarta. 